\title{
AN ANALYSIS OF SELLERS' AND BUYERS' SPEECH ACTS IN DAILY TRANSACTIONAL COMMUNICATION AT BANYUASRI TRADITIONAL MARKET IN BULELENG
}

\author{
D.R Padmayanti, N.K Wedhanti, D.A.E Agustini \\ Jurusan Pendidikan Bahasa Inggris \\ Universitas Pendidikan Ganesha \\ Singaraja, Indonesia \\ e-mail: \{dian.risma, karina.wedhanti, eka.agustini\}@undiksha.ac.id
}

\begin{abstract}
This research aimed to analyze the forms and functions of speech acts that were found in daily transactional communication between sellers and buyers in Banyuasri traditional market. This research was descriptive qualitative approach since the main focus is about describing and explaining the phenomenon of speech acts that are used by sellers and buyers, the forms and also the functions of speech acts in the daily routines speech at market environment. The subjects of this research were 10 sellers and 10 buyers at Banyuasri traditional market. The data gathered were analyzed by using Miles and Huberman model, namely, collecting data, data reduction, data display and conclusion drawing. The result of the data shows the form of speech act mostly uses by the sellers and buyers at Banyuasri traditional market is representative illocutionary acts.
\end{abstract}

Keywords: Speech acts, speech acts' forms, speech acts' functions.

\begin{abstract}
Abstrak
Penelitian ini bertujuan untuk menganalisis bentuk dan fungsi tindak tutur yang ditemukan dalam komunikasi transaksional harian antara penjual dan pembeli di pasar tradisional Banyuasri. Penelitian ini adalah pendekatan kualitatif deskriptif karena fokus utamanya adalah mendeskripsikan dan menjelaskan fenomena tindak tutur yang digunakan oleh penjual dan pembeli, bentuk-bentuk dan juga fungsi-fungsi dalam percakapan seharihari di lingkungan pasar dan percakapan pembeli dan penjual. Subjek penelitian ini adalah 10 penjual dan 10 pembeli di pasar tradisional Banyuasri. Data yang terkumpul dianalisis dengan menggunakan model Miles dan Huberman, yaitu, pengumpulan data, reduksi data, display data dan penarikan kesimpulan. Hasil dari data menunjukkan bahwa ada bentukbentuk tindak tutur yang banyak digunakan oleh penjual dan pembeli di pasar tradisional Banyuasri adalah tindakan ilokusi yang representatif.
\end{abstract}

Kata kunci: Tindak tutur, bentuk tindak tutur, fungsi tindak tutur.

\section{INTRODUCTION}

Language is the most important tool in human life that is used as an intermediary to be able to communicate and related to each other. The existence of language in this case becomes a vital part that has many different meanings and functions. Many theories arise regarding the real definition of a language. According to Hauser, Chomsky and Fitch (2002), the word "language" has highly divergent meanings in different contexts and disciplines. In informal usage, a language is understood as a culturally specific communication system. In the varieties of modern linguistics the term "language" is used quite differently to refer to an internal component of the mind/brain (sometimes called "internal language" or "I-language"). While, Leech (1974) states that we use language in many different ways, some of these are, the informational, the expressive, the directive, the phatic, the aesthetic. We use language and that language is a part of society. Actually, any language varies according to, the nature 
of the society, what kind of people, and their attitudes. People use language according to their situation. The social background of any person can play an important role in the kind of language they have. In addition, llyas (2012) states when people speak, they use language to achieve a variety of functions like expressing different emotions, start an argument or even insult someone.

All of those theories refer to the functions that already have by the language itself. As with language definitions, many experts say that language has various functions according to the situation and conditions when the language is used. One of language function that underlies this research is directive language function.

The directive function is one of the language use that aim to influence the behavior or attitudes of others(Leech, 1974). When someone said something to us, we have to know what that person means or what is the exact message that contains in her or his utters. Some utters contains meaning more that it is actually utters. For the example, if someone asked you, "Do you know where the market is?" That question has a meaning more than it looks like. It is a simple yes no question but it needs something that we should do for that person. If one person asks that question, it means that he or she wants us to explain her or him they way to market. It does not know where the station is, so that it wants to explain the way to the station. Some utterances like that belong to what we call speech act.

The use of speech acts in our daily conversation cannot be avoided since all linguistic communication involves linguistic acts. One of the speeches used by the Balinese sellers since the sellers communicate with the buyers in their activities selling the goods in which the activities of happen among the sellers and the buyers. In selling the goods in the high price, the sellers will use certain speech act that may be different from the common people used in their daily communication. Meanwhile, the sellers must face the buyers who bargain their goods in order to get the cheapest price. In this activity the speech act dominated the buyers and the sellers' utterances to get the price agreed between the buyers and the sellers.

The study of speech act is very crucial in order to avoid the misunderstanding among the speakers. We need to distinguish the intention of the speakers to the hearers. Besides, this research, researcher focused on the speech act used by sellers and buyers during transaction process. They used certain speech that can lead them to the misunderstanding both of them if they cannot interpret the speaker utterance since we know that some speech act is performed in a given sentence, for a speaker may mean more than what they actually said, which interpretation itself will depend on the context where the utterance is said. Some of the certain types of speech act will dominate the conversation among speakers since there will be bargaining activity that will happen among them. Besides, the way of the speaker in their conversation also analyzed in order to know how the speaker produced their speech act in that sort of circumstances. Next, the reason for the kind of speech act also identified that could give us the explanation why certain speech acts dominated the conversation.

This research aimed to identify and find out the forms functions of speech acts those are found in daily transactional communication between sellers and buyers in Banyuasri traditional market.

\section{METHOD}

This study applied descriptive qualitative approach since the main focus is about describing and explaining the phenomenon of speech acts that are used by sellers and buyers, the forms and also the functions of it in the daily routines speech at market environment and the conversation of buyers and sellers. More specifically, this research is categorized as naturally occurring data. According to Ritchie and Lewis (2003:34) many of the methods used in qualitative research were developed to allow investigation of phenomena in their natural settings. They provide data which is an 'enactment' of social behavior in its own social setting, rather than a 'recounting' of it generated specifically for the research study.

The main subjects of this study are sellers and buyers at Banyuasri Traditional Market. The subjects are chosen by purposive sampling because they are particular features or characteristics which will enable detailed exploration and understanding of the central 
themes. Members of a sample are chosen with a 'purpose' to represent a location or type in relation to a key criterion.

The data in this research were collected through some steps. There were a number of instruments that used to collect the data, such as the researcher as the main instrument, audio recorder, and field note. The researcher observed and listened directly to the buyers' and sellers' conversation to get data. Here, the researcher acted as the observer who used a blank sheet of paper and audio recorder to record the buyers' and sellers' activities during the observation. Researcher used audio recorder to record all of the utterances produced by sellers and buyers in any process of transaction at Banyuasri traditional market. The result of recording transcribed into written form in order to be able to answer the two research problems of this study. By recording, the researcher could avoid to lose the important data that related with the study.

The writer noted down key points about speech activity of the buyers and seller intensively. The result of observation process then transcribed into written form. The researcher selected some data from the transcription to get the important and appropriate data based on the focus of this research. Then, the last step is Conclusion drawing and verification are the final analytical step for this qualitative research. The first conclusion which has been obtained after the data display is a temporary conclusion. However, this conclusion can be a reliable conclusion that can answer the research question of this study, if there are proofs that can answer the research questions. In this study, there are two research questions. The conclusion achieved if the conclusion can answer the research question of this study. The data that needed to answer the research question in this study are the utterances between sellers and buyers at Banyuasri traditional market.

\section{FINDINGS AND DISCUSSION}

Forms of Speech Act

\begin{tabular}{lcll}
\hline No. Forms of & Data Meaning \\
& Speech Act & & \\
& & \\
\end{tabular}

1 Representative $\quad$ Data 1 Stating

Data 4 Stating

Data 5 Stating

Data 1 Reporting

Data 4 Reporting

Data 6 Reporting 
Data 8 Reporting

Data 2 Affirming

Data 3 Affirming

Data 7 Affirming

Data 8 Affirming

Data 9 Affirming

Data 1 Refusing

Data 6 Refusing

Data 7 Refusing

Data 9 Suggesting

2 Directive

Data 1 Requesting

Data 1 Requesting

Data 2 Requesting

Data 3 Requesting 
Data $7 \quad$ Requesting

Data 8 Requesting

Data Requesting

10

Data 2 Asking

Data 2 Asking

Data 3 Asking

Data 3 Asking

Data 5 Asking

Data 8 Asking

Data 9 Asking

Data 4 Demanding

Data 4 Begging

Data 8 Recommendi

ng

3 Commisive Data 5 Offering 
Data 6 Offering

\section{Data 7 Offering}

Data Offering

10

\section{Expressive Data 1 Praising}

\section{Data 4 Apologizing}

Data 7 Thanking

Data 9 Apologizing

Data Apologizing

10

5 Declarative Data 1 Naming

\section{Representative}

The utterance involved in stating of representative is as follow:

\section{Data 1}

B : "Dadi yang meli poh e ne bu?"

(Can I have that mango, Madam?)

S : "Poh 15 gen be to."

(It is only fifteen thousand rupiahs)

In the description of this dialogue, seller and buyer talked about the price of the mango. This utterance is including into representative stating. The seller gave the exact price of the mango to the buyer. She claimed that the mango cost five thousand rupiahs per kilogram in order to answer buyer's order.

\section{Data 4}

B : "Buih adi gede gati niki." 
(How can these is become so big?)

$S \quad$ : “Ten gede gati nike, pas pun nike. Sedeng pun nike adane."

(No, it is not too big, I think this is the good one.)

The conversation above took a place at a fruit stall that sold papayas. The buyer wanted to buy a papaya in a medium size, but she found that papayas were too big. She requested another papaya to the buyer. The seller tried to convince the buyer by saying the fact that papaya's size is already fits with buyer's order. Those utterances that uttered by the seller related with stating in representative of illocutionary acts according to Searle (in Leech, 1983:105).

\section{Directive}

The utterance involved in requesting of directive is as follow:

\section{Data 2}

B : "Maan 8 ribu ne sumagane bu?"

(Can I get these oranges for eight thousand rupiahs, Madam?)

S : "12 ribu geen sing dadi tawah. Anak manis cara gula ne."

(It is only twelve thousand rupiahs and could not be less. It is as sweet as sugar.)

This utterance uttered by the buyer that wanted to buy orange with eight thousand rupiahs. She requested that price before the seller told the exact price to the buyer. The expression showed by the buyer belongs to requesting of directive.

\section{Data 10}

S : "Napi bu?"

(What can I do for you?)

B : "Ngalih bumbu, bumbu pecel. Pecel santok nike."

(I am looking for peanut sauce. Peanut sauce.)

The conversation began when the seller asked the buyer about the things that buyer wanted to buy. Then the buyer answered by saying utterance that belongs to requesting type of directive. She gave exact request to the buyer by saying kinds of stuff that she wanted to buy.

\section{Commissive}

The utterance involved in offering of commissive is as follow:

\section{Data 5}

S : "Nah sepuluh deen be nah?"

(Ten thousand rupiahs, okay?

B : "Mun baang aji delapan ribu, jemak tiang akilo."

(If you give me eight thousand rupiahs, I will take one kilogram.)

The conversation above shows interaction between orange seller and buyer. The seller offered orange with ten thousand rupiahs in order to reach the final agreement with buyer. She said "Nah sepuluh deen be nah?" the word "...nah?", means that the seller asked agreement for the buyer. Then buyer said utterance that showing that she would buy the orange if the seller gave it with the price offered the buyer. This utterance uttered by the buyer can be included in the form of offering since this utterance means there would be action after the speaker deliver statement.

\section{Data 10}

S : "Tahu ten ngalih?"

(Don't you want to have tofu?) 
The utterance above shows the expression of offering of commissive. The seller in this situation tried to offer stuff to the buyer. She hoped buyer as the hearer would add her list of order and bought it. If the buyer accepted her offer, the seller already prepared the stuff and gave it to the buyer.

\section{Expressive}

The utterance involved in expressive is as follow:

\section{Data 1}

B : "Arum manis, care yang bu, o?"

(Arum manis, sweet as me right?)

S : "To care anake ne meli mare jegeg."

(It is as beautiful as the one who bought it.)

The conversation above shows about seller way to giving praise for her buyer. The buyer firstly delivered a joke by asking to the buyer whether the mango sweet or not as her. Then the seller answered by giving analogy to the buyer by saying that the mango was as sweet as the buyer who bought it.

\section{Data 10}

\section{S : : "Ampura gati bu, lima ribu manten. Maan limang atus bu."}

(No, I am sorry, it is only five thousand rupiahs. I only get five hundred rupiahs.)

The expression uttered by the seller to the buyer. She showed her politeness to the buyer since she could not give lower price again. She explained to the buyer that she got only five hundred rupiahs as her profit. Because of that she used apologizing of expressive illocutionary act.

\section{Declarative}

The utterance involved in naming of declarative is as follow:

\section{Data 1}

B : "Poh ape ne bu?"

(What is the name of this mango, Madam?)

$\mathrm{S} \quad$ : "Arum Manis ne adane."

(This is Arum Manis mango.)

The conversation above contained simple meaning where the buyer asked about the type of the mango, then the seller answered it. The seller told the name of the mango since the buyer asked about its name. This expression shows that it included in naming of declarative.

\section{The functions of Speech Act}

\section{Competitive}

\section{Data 7 \\ B : "Numbas abedik manten tiang." \\ (I only buy a little)}

This utterance took a place at vegetables stall. The buyer gave command to the seller that she only wanted a little amount of chilies when the buyer offered stuff to her. She 
asserted seller that she only need a little amount of chilies. So, it can be concluded that the utterance uttered by the buyer indicates the function is ordering of competitive.

\title{
Data 8
}

\section{B : "Baas kone pade akilo bu."}

(Give me also one kilogram of rice)

The buyer in this conversation commanded the seller to give her stuff. She commanded d by saying "Baas kone pade akilo bu" which means that she wanted another stuff too added in her list of order. The function of this utterance belongs to ordering of competitive.

\section{Convivial}

\section{Data 3}

S : "18 jemak koh"

(Just take it with eight thousand rupiahs.)

B : "Patuang be 12 jemak, nyak?"

(Make it (price) same, l'll take them twelve thousand rupiahs, how?)

Participants in this conversation are mango seller and buyer. The buyer offered the price for papaya to the seller in order to get agreement from the seller before she bought it. The seller expressed utterance contained offering expression in which she gave another price to the seller. The function of this utterance can be included in the offering since the buyer said "Patuang be 12 jemak, nyak?" which means she would buy it if the seller gave agreed with that price.

\section{Data 5}

S : "Nah sepuluh deen be nah?"

(Ten thousand rupiahs, okay?

B : "Mun baang aji delapan ribu, jemak tiang akilo."

(If you give me eight thousand rupiahs, I will take one kilogram.)

The conversation above shows interaction between orange seller and buyer. The seller offered orange with ten thousand rupiahs in order to reach the final agreement with buyer. She said "Nah sepuluh deen be nah?" the word "...nah?", means that the seller asked agreement for the buyer. Then buyer said utterance that showing that she would buy the orange if the seller gave it with the price offered the buyer. The function of this utterance uttered by the buyer can be included in the offering since this utterance means the speaker (buyer) gave a bargaining to the hearer (seller).

\section{Collaborative}

\author{
Data 1 \\ B : "Dadi yang meli poh e ne bu?" \\ (Can I have that mango, Madam?) \\ S : "Poh 15 gen be to." \\ (It is only fifteen thousand \\ rupiahs)
}

In the description of this dialogue, seller and buyer talked about the price of the mango. The function of this utterance is including into collaborative announcing. The seller gave the exact price of the mango to the buyer. She announced that the mango cost five thousand rupiahs per kilogram in order to answer buyer's order. 


\title{
4. Conflictive
}

\author{
Data 1 \\ B : "Sing dadi kuang buin?" \\ (Can't it be less?) \\ $\mathrm{S} \quad$ : "Mih, ten ngidang tiang maang akenten, keweh ngalih bati. Neh aliange \\ je ne masak di punya." \\ (No, I can't give it, it is hard to get profit.)
}

The conversation above shows the refusal from the mango seller who wanted to maintain the price of the mango. She refused buyer's offer that wanted to decrease the price. The buyer also gave a statement "...keweh ngalih bati" in order to strengthen her reason behind her refusal to buyer's offer. In conclusion this utterance can be involved in conflictive refusing.

\section{CONCLUSION AND SUGGESTION}

In this research, the researcher focused on two main things, namely the forms and functions of speech acts. The researcher used theory of Searle in Leech (1983). The subjects of this research were seller and buyer at Banyuasri traditional market.

In finding, the researcher found that the form of speech act most pronounced by seller and buyer in their daily transactional was representative illocutionary act, exactly affirming. This research showed the forms of speech act mostly used by seller and buyer at Banyuasri traditional market was representative illocutionary acts. In order to make it clear, the results were affirming about 31 out of 138 utterances (22.5\%), asking 27 out of 138 utterances $(19.6 \%)$, requesting 17 out of 138 utterances (12.3\%), stating and refusing 8 out of 138 utterances (5.8\%), demanding 6 out of 138 utterances (4.3\%), offering and naming 4 out of 138 utterances $(2.9 \%)$, thanking and ordering 3 out of $138(2.2 \%)$, begging 2 out of 138 utterances (1.4\%) and apologizing 1 out of $138(0.7 \%)$.

Then, the second concern of this research is functions of speech act based on the utterance uttered by seller and buyer at Banyuasri traditional market. In addition, the on the function of speech act used by seller and buyer, the most dominant function used is competitive. There were asking 37 out of 138 utterances (26.8\%), asserting 29 out of 138 utterances $(21 \%)$, refusing 14 out of 138 utterances $(10.1 \%)$, reporting 12 out of 138 utterances (8.7\%), announcing 11 out of 138 utterances (8\%), offering 8 out of 138 utterances $(5.8 \%)$, ordering 7 out of 138 utterances $(5.2 \%)$, demanding 6 out of 138 utterances $(4.3 \%)$, begging and apologizing 1 out of 138 utterances $(0.7 \%)$.

This research expects to be beneficial to the study of pragmatic and the complement to the study of the forms and functions of speech acts. In addition, researcher expects that the study can contribute to the development of pragmatics study, especially among the people who are interested in the pragmatics study. The researcher also expects that the readers can take information about the forms and also the functions of speech acts that are found in daily transactional communication in Banyuasri traditional market. Besides, expand insight of language, and use reference of research later. 


\section{REFERENCES}

Austin, J. L. 1962. How to do Things with Words. London: Oxford University

Cresswell, John W. 2014. Research Design: Qualitative, Quantitative, and Mixed Methods Approaches (4 $4^{\text {th }}$ Edition). United States of America: Sage Publication, Inc.

Essays, UK. (November 2013). Five Functions of Language (Leech, 1974). Retrieved from https://www.ukessays.com/essays/english-language/five-functions-of-languageenglish-language-essay.php?vref=1

Farid Ahmad. 2018. Illocutionary Acts Expressed on Gary Webb in "Kill the Messenger" Movie. Surabaya: State Islamic University of SunanAmpel

Hadi, Muhammad. 2012. An Analyis of Buyers' and Seller's Speech Acts in Daily Transactional Communication at Kebumen Traditional Market in Banyubiru. Salatiga:STAIN

Hana, Rikhan. 2012. Speech Acts in the Movie Script of Confession of A Shopaholic by P.J. Hogan. Kudus: University of Muria Kudus

Hauser, Marc D, Chomsky, Noam, Fitch,W. (2002) "The Faculty of Language: What is it, Who Has it, and How Did it Evolve?" Science's Compass 1569-1571

llyas, Sanna. (2012) "Facebook Status Updates: A Speech Act Analysis," Academic Research International, Vol.3, No. 2 .500-506

Junaidi, Khoirunnisa. 2017. An Analysis of Representative Speech Acts in Teaching and Learning Process on the Speaking Class of the Third Semester in English Department of IAIN Surakarta. Surakarta:The State Islamic Institute of Surakarta

Kurniasari, Putri. 2014. The Differences Between Anna's and Elsa's Characters Based on Their Speech Acts in Frozen Movie.Yogyakarta: State Islamic University SunanKalijaga

Mack N, Woodsong C, McQueen KM, Guest G, Namey E. 2005.Qualitative Research Methods: A Data Collector's Field Guide. NC: Family Health International

Miles, MB. andHuberman, AM. 1994. Qualitative Data Analysis (2nd edition). Thoushand Oaks, CA:Sage Publication

Nika, Gede. 2012. The Analysis of Speech Act Used by Shopkeepers and Customers during Selling and Buying Activities. Denpasar:Udayana University

Pease, A. 1981.Body Language, Sydney, Australia: Camel Publishing Company

Ritchie, Jane and Lewis, Jane. 2003. Qualitative Research Practice A Guide for Social Science Students and Researchers. London: Sage Publications

Searle, J. R. 1969, Speech Acts. An Essay in the Philosophy of Language. Cambridge

Searle, John. 1976. A Classification of Illocutionary Acts. Language in Society. Cambridge: Cambridge University Press

Searle, John. 1979. Expression and meaning: Studies in the theory of speech acts. Cambridge, England: Cambridge University

Strawson ,P. F. (1964) "Intention and Convention in Speech Acts," The Philosophical Review, Vol. 73, No. 4. 439-460.

Wilkinson, David and Birmingham, Peter. 2003. Using Research Instruments A Guide for Researcher. London:RoutledgeFalmer

Yule, George. 1996. Pragmatics. Hong Kong: Oxford University Press. 